\title{
POLA TUMBUH Brachiaria humidicola cv. Tully DI BAWAH TEGAKAN KELAPA
}

\author{
Selvie D. Anis, F. Dompas, dan W. Kaunang \\ Fakultas Peternakan Universitas Sam Ratulangi \\ E-mail : selvie_anis@yahoo.com
}

\begin{abstract}
ABSTRAK
Penelitian bertujuan untuk mempelajari pola tumbuh Brachiaria humidicola cv. Tully yang bertumbuh di bawah tegakan pohon kelapa. Penelitian dilaksanakan di Balai Penelitian Kelapa dan Palma Lain (BALITKA) Manado sejak April-Juli 2011. Variabel yang diukur terdiri dari pertumbuhan dan perkembangan berdasarkan jumlah tiller, jumlah buku dan panjang stolon, data penunjang suhu maksimum-minimum. Data dihitung dengan menggunakan analisis sederhana rata-rata, standar deviasi dan persamaan regresi. Hasil menunjukkan bahwa jumlah buku dan panjang stolon tetap stabil meningkat sampai dengan umur 10 minggu setelah tanam (MST) tetapi jumlah tiller maksimum tercapai pada umur 8 MST, kemudian mulai menurun pada umur 10 MST. Selanjutnya pertambahan jumlah buku, stolon dan tiller berkorelasi positif dengan umur tanaman dan mengikuti kurva pertumbuhan normal.
\end{abstract}

\section{Kata kunci: pola tumbuh, Brachiaria humidicola, tegakan kelapa}

\section{PENDAHULUAN}

Memahami bagaimana tanaman rumput bertumbuh dan berkembang adalah sangat esensial untuk dapat mengelola dengan benar suatu padang rumput/ pastura. Rerumputan seperti tanaman hijau lainnya, menangkap energi dari matahari dan menyimpannya dalam bentuk gula dan karbohidrat, dimana semuanya itu akan digunakan bersama dengan unsur hara dan mineral lainnya untuk pembelahan sel, pertumbuhan, perkembangan dan reproduksi (Stichler, 2002).

Ketersediaan cahaya adalah faktor ekologis utama yang mempengaruhi pertumbuhan dan daya hidup tanaman. Tanaman dapat meresponinya dengan beradaptasi secara genetis dan secara aklimatisasi fenotipik terhadap level cahaya yang rendah (Lambers et al., 1998; Guenni et al., 2008). Terdapat tiga respons aklimatisasi terhadap naungan yakni: a) dengan mengurangi kecepatan respirasi, b) menaikkan perbandingan pucuk terhadap akar, dan c) menaikkan luas daun spesifik (Humphrey, 1994; Lambers et al., 1998).

Pengembangan pastura di areal tegakan kelapa diperhadapkan dengan masalah naungan yang menyebabkan menghilangnya jenis tanaman pastura dan digantikan dengan gulma yang tidak edible sebagai pakan. Masalah ini dapat diatasi dengan diintroduksikan jenis hijauan yang toleran terhadap naungan, di antaranya adalah rumput Brachiaria humidicola cv Tully dan direkomendasikan sebagai pastura penggembalaan di areal tegakan kelapa (Mullen et al., 1998). Namun demikian, biasanya rerumputan tersebut mengalami kerusakan ketika digembalai secara bebas tanpa manajemen (free grazing) sebagaimana lazim diterapkan oleh petani/ peternak.

Penggembalaan ternak sapi di areal pertanaman kelapa adalah sistem yang telah lama diterapkan. Keuntungan sistem ini berupa multi fungsi dari lahan, termasuk: (a) meningkatkan dan diversifikasi pendapatan; (b) penggunaan sumber daya lahan terbatas dengan lebih efisien; (c) stabilisasi tanah, dan (d) potensial untuk meingkatkan produksi perkebunan kelapa melalui kontrol gulma lebih baik, daur ulang unsur hara dan penyediaan nitrogen (Shelton dan Stur, 1991). Kendatipun sistem ini memberikan berbagai keuntungan, namun hal itu tidak bertahan lama karena masalah menghilangnya pastura atau dikenal dengan fenomena pasture rundown atau terjadinya kelesuhan, bahkan kerusakan padang rumput.

Beberapa hasil penelitian menunjukkan bahwa penyebab masalah tersebut adalah jenis hijauan yang digunakan tidak toleran terhadap naungan, dan tidak tahan terhadap injakan dan renggutan oleh ternak sapi (Watson dan Whiteman, 1981a). Untuk mengatasi masalah tersebut melalui proyek penelitian yang disponsori oleh ACIAR dilakukan screening dari sekitar 50 jenis hijauan rumput tropis yang diintroduksi ke Indonesia sebagai pastura penggembalaan di areal pertanaman kelapa, dan ditemukan bahwa Brachiaria humidicola $\mathrm{cv}$. Tully termasuk salah satu jenis rumput yang direkomendasikan untuk dikembangkan pada lahan perkebunan seperti di bawah tegakan kelapa di Manado (Kaligis dan Sumolang, 1998), di Bali ( Rika et al., 1991) dan di Malaysia pada areal pertanaman karet (Ng, 1991). Walaupun demikian rumput-rumput ini tetap mengalami kerusakan ketika digembalai secara bebas (free grazing) atau tanpa manajemen penggembalan yang benar. Hasil ini menunjukkan 
bahwa penyebab kerusakan pastura tidak sematamata terletak hanya pada masalah toleransi hijauan pada naungan, tetapi juga faktor manajemen penggembalaan yang tidak tepat, dan yang tidak dapat menjamin terpeliharanya kesehatan pastura.

Bagaimana pola pertumbuhan rumput Brachiaria humidicola pada kondisi ternaung di areal tegakan kelapa akan dipelajari dalam penelitian pendahuluan ini, dimana hasilnya akan menjadi acuan untuk penelitian lanjut.

\section{MATERI DAN METODE}

\section{Tempat dan Waktu}

Penelitian ini dilaksanakan di lahan tegakan kelapa Balai Penelitian Kelapa dan Palma lainnya (BALITKA) di Desa Paniki Manado, Sulawesi Utara, sejak awal Januari 2008 sampai dengan akhir Maret 2008. (Gambar 1).

\section{Bahan dan Alat}

Bahan yang digunakan berupa anakan rumput $B$. humidicola dengan ukuran panjang $15 \mathrm{~cm}$, dengan memiliki 2,5 daun muda dan akar sekunder. Peralatan yang digunakan berupa gunting rumput, Herbisida -Rambo digunakan untuk gulma rerumputan, kemudian untuk gulma berdaun lebar digunakan DM-6. Selanjutnya lahan diolah untuk dapatkan keseragaman media tumbuh yang optimal dan siap ditanami.
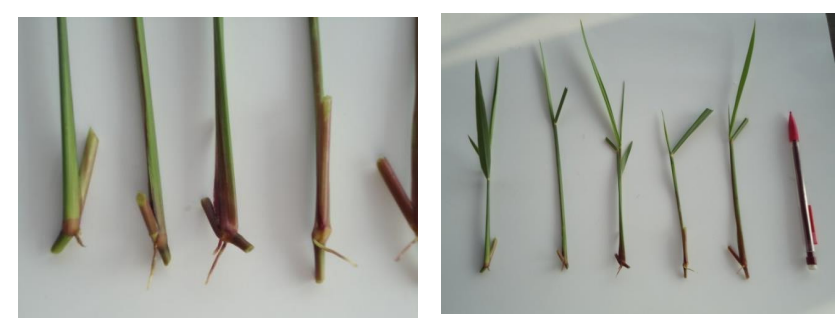

Gambar 2. Anakan Bibit Vegetatif yang Digunakan

Sebanyak lima tanaman dijadikan sampel dan ditanam dengan jarak tanam 1,5 meter untuk memudahkan pengukuran, mengingat sifat tumbuh rumput ini yang merambat. Variabel yang diukur pada percobaan ini adalah jumlah buku dan panjang stolon, keduanya diukur pada tanaman induk (mother), sedangkan jumlah anakan (tiller) diperoleh dengan menghitung semua anakan yang dihasilkan oleh tanaman induk selama pengamatan (Gambar 3).

\section{Metode Penelitian}

Rumput percobaan ditanam sebanyak dua tanaman, kemudian tiga minggu setelah tanam (MST) dipilih satu tanaman yang vigor dan dibiarkan tumbuh secara tunggal. Sebanyak lima tanaman dijadikan

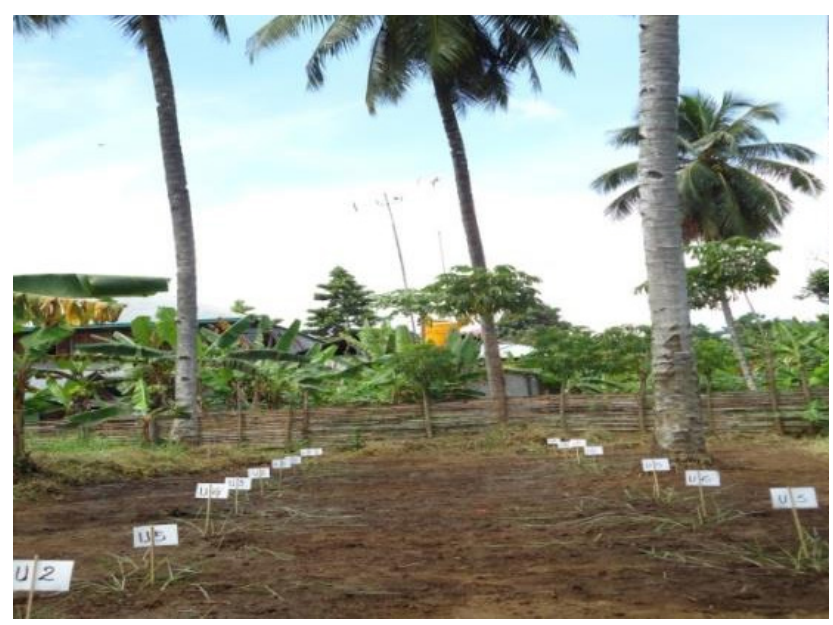

Gambar 3. a. Lahan percobaan.

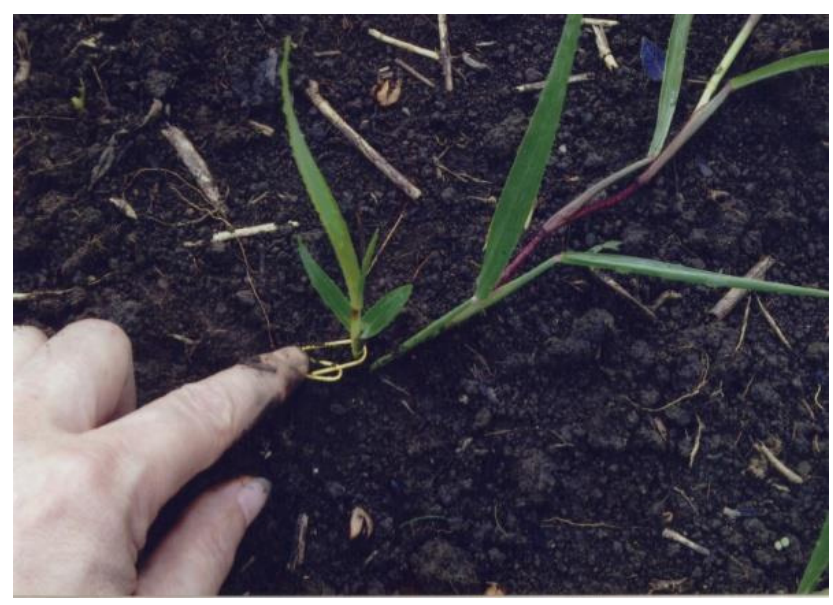

Gambar 3b. Contoh Tanaman Induk dan Anakan.

sampel dan ditanam dengan jarak tanam 1,5 meter untuk memudahkan pengukuran, mengingat sifat tumbuh rumput ini yang merambat. Variabel yang diukur pada percobaan ini adalah jumlah buku dan panjang stolon, keduanya diukur pada tanaman induk (mother), sedangkan jumlah anakan (tiller) diperoleh dengan menghitung semua anakan yang dihasilkan oleh tanaman induk selama pengamatan (Gambar 3b).

Untuk melihat dan mengukur pertumbuhan dan perkembangan vegetatif tanaman, maka periode pengukuran telah dilakukan setiap 2 minggu yaitu minggu ke 2, ke 4, ke 6, ke 8 dan minggu ke 10 setelah tanam, atau sepanjang fase pertumbuhan vegetatif sampai fase perpanjangan tanaman dan sebelum masuk fase generatif atau berbunga. Nilai jumlah buku diperoleh dari hasil penjumlahan banyaknya buku pada tiap periode pengukuran. Nilai panjang stolon adalah hasil pengukuran panjang stolon pada periode terakhir yaitu minggu kesepuluh. Sedangkan nilai jumlah anakan merupakan penjumlahan banyaknya anakan pada setiap periode pengukuran. Selanjutnya dengan membagi panjang stolon (PS) dengan jumlah buku (JB) pada tanaman tersebut, 
diperoleh rata-rata panjang setiap ruas pada tanaman sampel. Untuk dapatkan pola tumbuh rumput $B$. humidicola selama perkembangannya dianalisis hubungan korelasi antara masing-masing variabel yang diukur dengan waktu atau umur tanaman (Steel and Torrie, 1989).

\section{HASIL DAN PEMBAHASAN}

\section{Jumlah Buku, Panjang Stolon dan Jumlah Anakan}

Persistensi suatu tanaman pakan diindikasikan melalui beberapa parameter diantaranya dihitung dari jumlah buku, panjang stolon dan jumlah anakan. Analisis ragam menunjukkan adanya pengaruh interaksi perlakuan pemupukan dan umur tanaman terhadap parameter jumlah buku dan panjang stolon (Tabel 1).

Dari Tabel 1 terlihat bahwa jumlah buku selama periode pengamatan dari lima tanaman sampel berkisar antara 18 sampai 21 buku. Panjang stolon tanaman induk selama periode pengukuran bervariasi antara $107 \mathrm{~cm}$ sampai $135 \mathrm{~cm}$. Bila dihitung perbandingan antara panjang stolon tanaman induk dan jumlah buku pada tanaman induk tersebut diperoleh rasio $\mathrm{PT} / \mathrm{JB}$ bervariasi antara 5,50 sampai 7,50 atau panjang ruas $(\mathrm{cm})$ antara dua buku berturutan pada tanaman sampel bervarisi mengikuti rasio tersebut. Artinya panjang ruas tidak sama rata, sebagaimana kenyataan di lapang bahwa panjang ruas pada bagian pangkal tanaman cenderung lebih pendek dibandingkan panjang ruas pada bagian pucuk tanaman (Gambar 4 b). Hal ini terjadi mungkin karena pada bagian pucuk tanaman aktivitas fotosintesis lebih aktif, dan diikuti dengan akumulasi fotosintat lebih banyak sehingga stimulasi terhadap perpanjangan tanaman lebih aktif. Abdullah (2009) mengatakan panjang tanaman ditunjang oleh jumlah buku dan panjang ruas. Selanjutnya jumlah anakan yang dihasilkan oleh tanaman induk bervariasi antara 9 sampai 12 buah.

Tabel 1. Jumlah buku (JB), panjang solon (PS) dan jumlah anakan per tanaman

\begin{tabular}{ccccc}
\hline $\begin{array}{c}\text { Nomor. } \\
\text { Tanaman }\end{array}$ & Jumlah buku & $\begin{array}{c}\text { Panjang } \\
\text { stolon }\end{array}$ & $\begin{array}{c}\text { Rasio } \\
\text { PS/JB }\end{array}$ & $\begin{array}{c}\text { Jumlah } \\
\text { anakan }\end{array}$ \\
\hline 1 & 19 & 107 & 5,63 & 10 \\
2 & 18 & 135 & 7,50 & 9 \\
3 & 20 & 110 & 5,50 & 10 \\
4 & 19 & 115 & 6,05 & 12 \\
5 & 21 & 125 & 5,95 & 11 \\
\hline
\end{tabular}

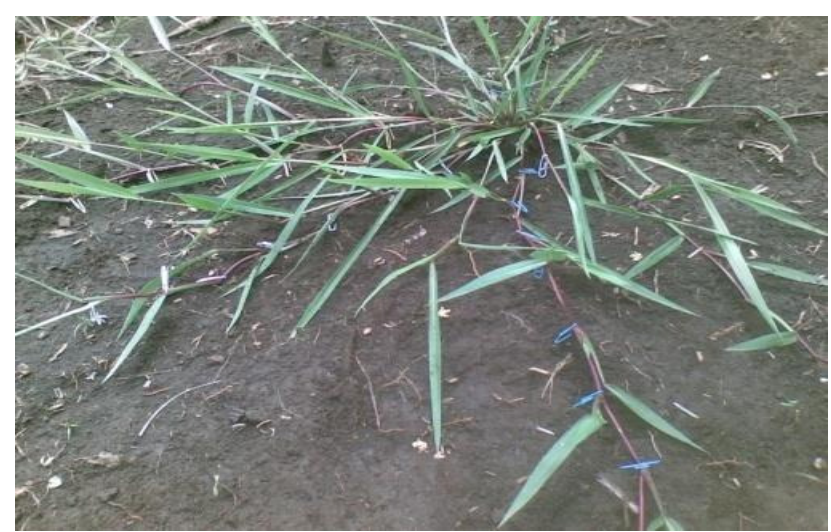

Gambar 4. a. Jumlah buku dan panjang stolon tanaman induk (tanda biru).

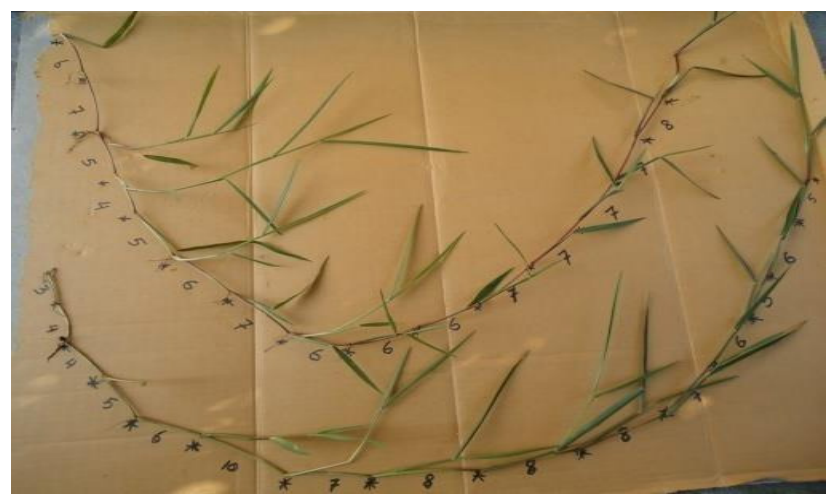

Gambar 4b.Jumlah buku, panjang ruas dan panjang stolon tanaman induk.

\section{Pola tumbuh rumput Brachiaria humidicola}

Rataan penambahan jumlah buku, panjang stolon dan penambahan jumlah anakan disajikan pada Tabel 2.

Tabel 2. Rataan Penambahan Jumlah Buku, Panjang Stolon dan Penambahan Jumlah Anakan pada Setiap Umur Pengamatan

\begin{tabular}{cccc}
\hline $\begin{array}{c}\text { Umur tanaman } \\
\text { (MST) }\end{array}$ & $\begin{array}{c}\text { Tambahan jumlah } \\
\text { buku }\end{array}$ & Panjang stolon & $\begin{array}{c}\text { Penambahan } \\
\text { jumlah anakan }\end{array}$ \\
\hline 2 & 3,40 & 20,60 & 1,20 \\
4 & 3,80 & 37,80 & 1,80 \\
6 & 4,00 & 50,80 & 2,00 \\
8 & 4,15 & 70,60 & 3,20 \\
10 & 4,20 & 85,80 & 2,60 \\
\hline
\end{tabular}

\section{a. Jumlah buku}

Pertumbuhan tanaman selalu terkait dengan waktu tumbuh atau umur tanaman. Tabel 2 menunjukkan bahwa jumlah buku bertambah setiap 2 minggu selama periode pengukuran sampai umur 10 minggu. Untuk melihat seberapa besar keeratan hubungan variable jumlah buku dipengaruhi oleh waktu atau umur tanaman dilakukan analisis regresi. Hasil analisis statistik menunjukkan bahwa jumlah buku sangat dipengaruhi oleh waktu tumbuh atau dengan umur tanaman, dan bentuk hubungan mengikuti persamaan linier $\mathrm{y}=3,835+0,003750 \mathrm{x}$, dimana Y menunjukkan variable jumlah buku, dan $\mathrm{x}$ adalah waktu tumbuh tanaman, dengan koefisien regresi $\mathrm{R}^{2}$ 
$=98,7 \%$. Artinya jumlah buku 98,7\% ditentukan oleh umur tanaman (Gambar 5).

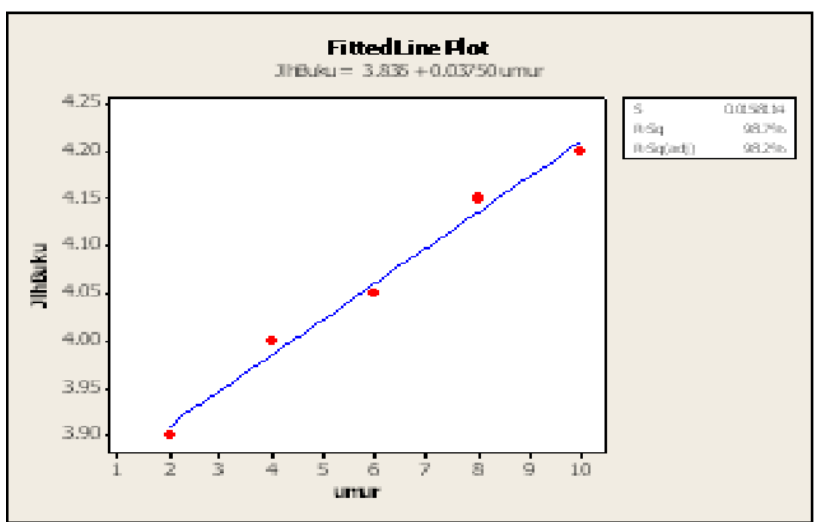

Gambar 5. Hubungan antara jumlah buku dan umur tanaman

Pertambahan jumlah buku secara linier sangat membantu menaikkan produksi biomassa rumput $B$. humidicola karena pada setiap buku yang menyentuh tanah mengeluarkan anakan baru atau tiller yang memungkinkan tanaman untuk bertumbuh, menyebar dan menghasilkan daun dan batang baru, sebagai karakter tanaman yang berkembang dengan stolon (Wong and Stur, 1994).

\section{b. Panjang stolon tanaman induk}

Tabel 2 menunjukkan pertambahan panjang stolon dari 20,60 $\mathrm{cm}$ pada umur 2 minggu dan meningkat bertahap pada 4 minggu $37,80 \mathrm{~cm}$, pada umur 6 minggu 50,80 cm, pada umur 8 minggu $70,60 \mathrm{~cm}$ dan menjadi $85,80 \mathrm{~cm}$ pada umur ke 10 minggu.

Panjang stolon tanaman induk berhubungan erat dengan waktu tumbuh atau umur tanaman mengikuti persamaan regresi linier y $=4,160+8,160 \mathrm{x}$, dengan koefisien regresi $\mathrm{R}^{2}=99,7 \%$ (Gambar 6). Artinya panjang tanaman 99,7\% ditentukan oleh waktu atau umur tanaman. Data menunjukkan bahwa pola tumbuh $B$. humidicola sampai dengan umur 10 minggu masih menunjukkan kecenderungan meningkat. Peningkatan panjang stolon tanaman induk ini sejalan dengan bertambahnya jumlah buku yang diikuti dengan bertambahnya panjang ruas, yang meningkat secara linier mengikuti waktu perkembangan (Gambar 5). Hal ini menunjukkan salah satu karakter persistensi dari rerumputan yang berkembang dengan stolon (Wong and Stur, 1991), terutama yang hidup secara tunggal dimana persaingan unsur hara, air dan cahaya matahari relatif rendah (McMaster et al., 2003). Hasil ini berbeda dengan tanaman rumput $B$. humidicola yang tumbuh dalam komunitas dimana panjang stolon cenderung menurun ketika memasuki minggu ke 10 dan berhenti pada umur 12 minggu sebab terjadi tumpeng tindih karena kekurangan ruang tumbuh. (Abdullah, 2009).

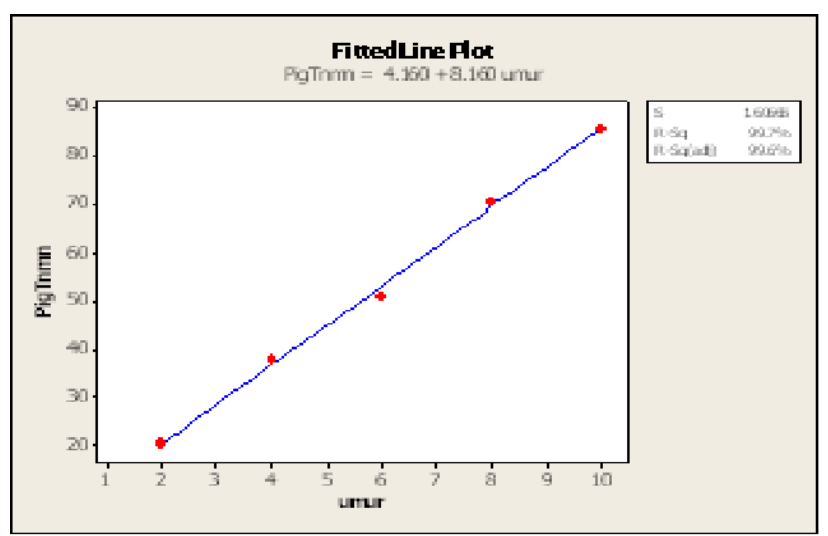

Gambar 6. Hubungan antara panjang stolon tanaman dan umur tanaman

\section{c. Jumlah anakan}

Rataan jumlah anakan terbanyak dihasilkan pada tanaman berumur 8 minggu sebanyak

3,20 anakan dan menurun pada umur 10 minggu dengan rataan jumlah anakan sebanyak 2,60 (Tabel 2). Hal ini menunjukkan bahwa pada umur 8 minggu proses regenerasi vegetatif mulai terjadi, sebagaimana perkembangan rumput pada umumnya (tropical forages). Terjadi penurunan jumlah anakan pada umur 10 minggu mungkin pada umur tersebut kepadatan populasi anakan mulai tinggi, sehingga terjadi tumpang tindih dan persaingan tempat (Abdullah, 2009).

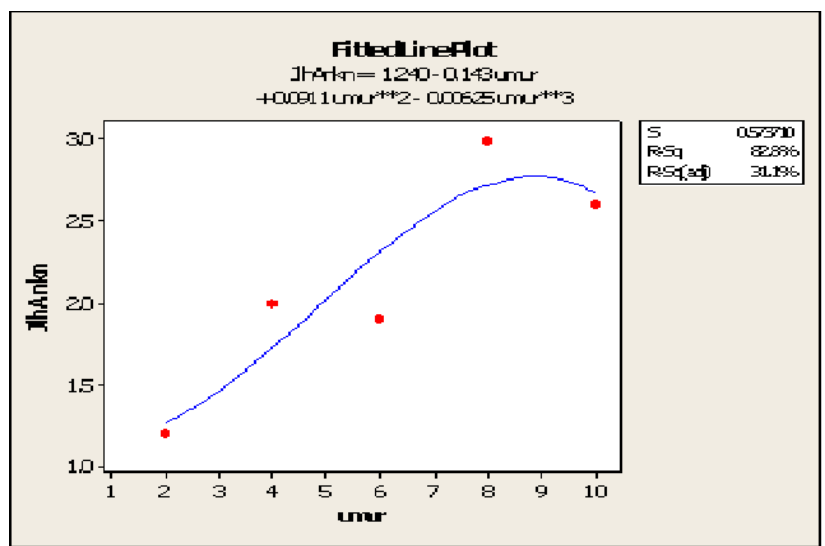

Gambar 7. Hubungan antara jumlah anakan dan umur tanaman

Sebagaimana parameter yang lain, variabel jumlah anakan perkembangannya terkait dengan bertambahnya umur tanaman. Analisis statistik menunjukkan adanya hubungan erat antara jumlah anakan dengan waktu atau umur tanaman mengikuti persamaan kubik $\mathrm{y}=1,240-0,143 \mathrm{x}+0,0911 \mathrm{x}^{2}-$ $0,00625 \mathrm{x}^{3}$, dimana Y menunjukkan jumlah anakan dan $\mathrm{x}$ adalah waktu pertumbuhan, dengan koefisien regresi $\mathrm{R}^{2}=82,9 \%$ (Gambar 7). Artinya penambahan jumlah anakan ditentukan oleh waktu tumbuh atau umur tanaman, dimana hasil penelitian sebelumnya menunjukkan pertambahan jumlah anakan selalu mengikuti pola kubik (Emoto dan Ikeda, 2005). 
Jumlah anakan mulai menurun ketika memasuki umur tanaman 10 minggu.

Penurunan jumlah anakan tersebut diduga karena mulai terjadi persaingan cahaya antara daun yang berada pada lapisan tajuk bagian atas menyerap cahaya lebih banyak dari pada daun yang berada di lapisan bawah tajuk (Islam dan Hirata, 2005). Dengan terbatasnya intensitas cahaya yang diterima akan menginduksi penutupan stomata dan dapat mengakibatkan laju fotosintesis daun dilapisan tajuk bawah menjadi rendah (Allard et al., 1991).

\section{SIMPULAN}

Dari hasil penelitian ini dapat disimpulkan bahwa:

1. Jumlah buku dan panjang stolon tetap meningkat sampai dengan umur 10 MST, tetapi jumlah anakan terbanyak sampai umur 8 MST dan menurun pada 10 MST.

2. Bertambahnya jumlah buku, panjang stolon dan jumlah anakan berkorelasi positif dengan umur tanaman, dan tetap mengikuti pola tumbuh dan perkembangan normal.

\section{REFERENSI}

Allard, G., Nelson, C.J and S.G. Pallardy. 1991. Shade effect on growth of tall fescue: I. Leaf anatomy and dry matter partitioning. Crop Sci. 31: 163-167.

Abdullah, L. 2009. Pola pertumbuhan rumput Signal (Brachiaria humidicola (Rendle Schweick) pada padang penggembalaan dengan aplikasi sumber nutrient berbeda. Med. Pet. 32(1) $71-80$.

Busque. J. and M. Herrero. 2001. Sward structure and patterns of defoliation of signal (Brachiaria decumbens) pastures under different cattle grazing intensities Tropical Grassland 35: 193-204.

Emoto, $\mathrm{T}$ and H. Ikeda. 2005. Appearance and development of tiller in herbage grass species Timothy (Phleum pratense L.). Grassland Sci. 51: 45-54.

Espinoza, L., Slaton, N., and M. Mozaffari. 2007. Understanding the number on your soil test report. Cooperative Extention Services. http://www.uaex. edu. Downloaded 17/01/11.

Guenni, O., Seiter, S and R. Figueroa. 2008. Growth responses of three Brachiaria species to Light intensity and nitrogen supply. Tropical Grasslands 42: $75-87$.

Humphreys, L. R. 1991. Tropical Pasture Utilisation. Cambridge University.

Islam, M. A. and M. Hirata. 2005. Leaf appearance, death and detachment and tillering in Centipedgrass in comparison with bahiagrass (Paspalum notatum): A study at small sod Scale. Grassland Sci. 51: 121-127.
Ipinmoroti, R. R., Watanabe, T., and O. Ito. 2008. Effect of $B$. humidicola root exudates Rhizosphere soils, moisture and temperature regimes on nitrification inhibition in two Volcanic Ash soil of Japan. World $\mathrm{J}$ of Agrig. Sciences 4(1): 106-113.

Kaligis, D. A. 1998. Performance of pasture species under free grazing in Coconut plantation. In: Integrated Crop-Livestock Production System and Fodder Trees. Proc. $6^{\text {th }}$ Meeting of regional working group on grazing and Feed resources for Southeast Asia.

Lambers, H., Chapin, F. S., and Pons, T. L. 1998. Plant physiological Ecology. (Springer - Verlag: New York.

McMaster G. S., Wilhelm, W.W., Palig D. B., Porter, J. R., and P. D. Jamieson. 2003. Spring Wheat leaf appearance and temperatur: Extending the Paradigm? Annals of Botany 91:697-705.

Mullen, B. F., Rika, I K., Kaligis, D. A., and W.W. Stur. 1997. Performans of grass legumes pastures under coconut in Indonesia. Expl. Agric. 33: 409-423.

Ng, K. F. 1991. Forage Species for Rubber Plantations in Malaysia. In: Forages for Plantation Crops. Ed.: H. M. Shelton and W. W. Stur. ACIAR Proc. No 32.

Steel, R. G. D. and H. J. Torrie. 1989. Prinsip dan Prosudur Statistika: Suatu Pendekatan Biometrika (terjemahan). Penerbit PT. Gramedia, Jakarta.

Stichler, C. 2002. Grassgrowth and development. Texas A and M University. www.soilcrop.tamu.edu.

Rika, I K., Mendra, I K, and G. M. Oka. 1991. New forages species for coconut plantation in Bali. In: Forage for Plantation Crops. Ed.: H.M. Shelton and W.W. Stur. ACIAR Proc. No 32.

Skerman, P. J. and F. Riveros. 1990. Tropical Grasses. FAO. Rome.

Shelton, H. M and W. W. Stur. 1991. Opportunities for integration of ruminants in plantation crops in Southeast Asia and the Pasific. In: Forage for Plantation Crops. Ed.: H.M. Shelton and W.W. Stur. ACIAR Proc. No 32.

Tropical Forages. Brachiaria humidicola. http:// www.tropicalforages.infokey/Forages/Media/ $\mathrm{Htm} /$ Brachiaria humidicola.htm. Downloaded 12/01/2010.

Watson, S.E and P.C. Whiteman. 1981a. Grazing studies on the Guadacanal Plains, Salomon Island. 2. Effects of pasture mixed and stocking rate on Animal production and pasture component. J. of Agric.Sci. Cambridge $97: 353-364$.

Wong, C.C dan W.W. Stur.1994. Mechanisms of Persistence in Tropical Foreges to Defoliation under Shade. In: Integration of ruminants into plantation systems in Southeast Asia. Ed.: B.F. Mullen and H.M. Shelton. ACIAR Procc. No. 6. 